\title{
SWOT Analysis of Religious Tourism in the Roi Kaen Sarn Sin Cluster of Northeastern Thailand
}

\author{
Aree Naipinit ${ }^{1}$, Thirachaya Maneenetr ${ }^{1}$, Thongphon Promsaka Na Sakolnakorn ${ }^{2}$, Chidchanok Churngchow $^{3}$ \& \\ Patarapong Kroeksakul ${ }^{4}$ \\ ${ }^{1}$ Faculty of Management Science, Khon Kaen University, Khon Kaen, Thailand \\ ${ }^{2}$ Institute for Peace Studies, Prince of Songkla University, Hat Yai Campus, Thailand \\ ${ }^{3}$ Faculty of Education, Prince of Songkla University, Pattani Campus, Thailand \\ ${ }^{4}$ Faculty of Environmental Culture and Ecotourism, Srinakharinwirot University, Bangkok, Thailand \\ Correspondence: Aree Naipinit, Faculty of Management Science, Khon Kaen University, Khon Kaen, 40002, \\ Thailand.E-mail: arekul@kku.ac.th
}

Received: June 16, 2013 Accepted: July 17, 2013 Online Published: September 29, 2013

doi:10.5539/ass.v9n13p262

URL: http://dx.doi.org/10.5539/ass.v9n13p262

\begin{abstract}
This article aims to examine the strengths, weaknesses, opportunities, and threats for tourism in the Roi Kaen Sarn Sin (RKSS) cluster, using a qualitative approach to consider religious tourism in northeastern Thailand. Semi-structured interviews were the main data collection tools, and key informants of this study included officers from both government and private sectors related to tourism in northeastern Thailand. The results found that religious tourism took place within this area a long time ago. Elements of religious tourism in the RKSS cluster include 1) attractions, 2) accessibility, 3) accommodations, 4) safety, 5) activities supporting tourism, and 6) social issues. Opportunities and weaknesses of the provincial clusters, from the point of view of religious tourism, can be classified into several issues, including infrastructure and transportation, tourism attractions, religious activities, networks, and local beliefs; the development strategies for increasing potential for religious tourism are 1) transportation coverage through public transport and 2) local sectors that keep area monastery histories.
\end{abstract}

Keywords: Roi Kean Sarn Sin cluster, religious tourism, SWOT

\section{Introduction}

The northeastern region of Thailand was formerly declared a land of poverty. The region's geographical landscape is a plateau; the soil is mostly clay silt with good drainage that makes it hard to catch the water. Due to these conditions, the northeastern region is called "the most drought land of Thailand" (Buapan, 2002). In terms of culture and archaeology, the northeastern region is full of cultural aspects, and archaeological evidence has found a lot more in the areas nearby. Such evidence reflects the religious changes of people in years past (Suwit \& Dararat, 1998; Thawat, 1989), for instance, the Phimai sanctuary, which is full of etched patterns, reflects beliefs in Buddhism and Brahmanism. In addition, these signs also reflected the faith and beliefs of people at that time, and these were transferred to people of the next generation as tangible religious objects. For example, every village in the northeastern region has a temple that acts as the center of the village or community. These temples also have a history which describes well-known masters who performed and practiced many good things very well. Besides the faith aspect religion has been combined with tourism aspects, and this is called religious tourism and viewed as a sub-type of cultural tourism. This kind of tourism has been recognized as an alternative for some who are interested in the history of religious objects. Nowadays, this tourism alternative has spread. According to Sudatip's (2012) study, religious tourism currently is another form of tourism for people who are specifically interested in religion and archaeology, and it has been very popular in Thailand due to the Thai belief that worshipping sacred places or objects would bring prosperity to people's lives. The study found that temples counted as resources for religious tourism that reflect the civilization and local livelihoods. They are full of knowledge on history, architecture, fine arts, education, and the cultural links between community culture and the history of the local settlement as well (Manu, 1977; Wirot, 1995). 
The Roi Kaen Sarn Sin (RKSS) cluster was set up through the Thai government's strategies in 2003 for four provinces: Roi Et, Khon Kaen, Mahasarakham, and Kalasin. It aimed to develop a network for increasing the economic potential in this provinces group. However, this study of the clusters was conducted based on the following question: What are the strengths, weaknesses, opportunities, and threats for tourism in the Roi Kaen Sarn Sin (RKSS) cluster area? This question will prove the presence of tourism elements and potential for tourism resources. Nevertheless, this result can be further developed to improve and enhance religious tourism in the future.

\section{Objective}

To study the strengths, weaknesses, opportunities, and threats for tourism in the Roi Kaen Sarn Sin (RKSS) cluster.

\section{Literature Review}

\subsection{Tourism Elements}

According to Smith (1994), there are five tourism elements: 1) physical plants (PP), including location and travel affecting tourism, 2) freedom of choice (FC) in travel, 3) service providers (S), 4) involvement (I), a link between tourist attractions and activities, and 5) the hospitality $(\mathrm{H})$ of the overall service. Peter (2011) gave a suggestion about another element, which is the demand from tourists making decisions. However, these decisions depend on other factors such as economic status (Viorica \& Sorin, 2010), safety of tourist attractions, and public relations (Mekonnen, 2010). These elements are all associated with tourism attractions and the ability to respond to the needs of tourists.

\subsection{Alternative Tourism}

In a report by Istvan et al. (2012), the growth in alternative tourism is due to the above shortcomings of mass tourism, which are increasing. The global market is changing tourists' consumption behavior and has broadly impacted two types of tourism. In the past, tourists visited natural attractions, such as seasides, waterfalls, mountains, and caves, in order to observe natural phenomena, and they also visited manmade sites such as Buddhist temples, castles, palaces, and old buildings to appreciate their historic and aesthetic value. As people become wealthier and transportation improves, more tourists come to the sites visited by others in the past (Galvani, 2005). Today, there are several types of alternative tourism-ecotourism, community-based tourism, health tourism, gastronomic tourism, and rural tourism — which attract modern tourists (D'mello, 2008). Cultural tourism is also an attraction for them (Ratanakomut, 2006).

\subsection{Background of Religious Tourism}

The World Tourism Organization ([UNWTO], 2011) has said religious tourism is about the beliefs that people have transferred generation to generation, and it is a tool for identifying people's backgrounds and cultures in each area. These cultural aspects are presented as a form of tourism, including activities related to tradition, beliefs, and local ceremonies (Vidic, 2007). However, religious tourism may include a day of worship that is important in each religion (Angeles \& Javier, 2008). The Greek National Tourism Organization (2011), under the Ministry of Culture and Tourism stated that religious tourism is not new; it began even before the religion itself was born with the pilgrimage (Katri, 2012). Religious tourism then became an event that people participated in to worship at sacred places and to participate in activities such as releasing animals to the wild and giving alms. However, these activities are essential to the distribution of income to people around the area.

Many studies have attempted to define religious tourism; Istvan et al. (2012) say religious tourism refers to all travel to sites of religious importance that is motivated, at least partly, by religion. However, Vorzsak and Gut (2009) add that religious tourism means not only visiting sites, shrines, and structures with religious significance but also attending religious conferences, different culturally religious events, exhibitions of cultic objects, and concerts of sacred music.

\subsection{Background of the Roi Kaen Sarn Sin (RKSS) Cluster}

Strategic, clustered province management was an innovation among bureau administrators in terms of development vision and direction for every dimension within the cluster. In 2003, Thailand's government had set 19 provincial clusters, and the RKSS cluster is in the center of the northeastern region. RKSS, according to information from the Office of Strategy Management ([OSM], 2011), refers to the provinces of Khon Kaen, Mahasarakham, Roi Et, and Kalasin, which are located in the lower-northeastern region of Thailand. The total area of these provinces is approximately 31,423 square kilometers $(19,639,296$ acres), representing $18.6 \%$ of the total area in the northeastern region. The physical landscape is quite flat and interspersed with low mountains on the 
north side of Roi Et and Khon Kaen provinces, and the east side of Kalasin Province close to Phu Phan Mountain. Tourism in this area is unique, especially with regard to cultural and natural attractions such as Phra That Kham Kaen Monastery, Pueai Noi Castle, the National Museum in Khon Kaen Province, Phra That Na Dun Monastery (Mahasarakham) Prang Ku, Ku Ka Sing, Phra Maha Chedi Chai Mongkol Pagoda (Roi Et), City Museum of Kalasin, Phu Por Phra Monastery, and the Phra That Ya Coo Monastery (Kalasin). In addition, the provincial cluster also has various natural attractions such as Phu Pha Man National Park, Phu Wiang National Park, Ubonrat Dam (Khon Kaen), Ko Sum Pee Forest Park, Pa Doon Pan Lum (Mahasarakham), Plan Chai Pond, Pha Nam Yoi Forest Park (Roi Et), Sirindhorn Dinosaur Museum, Lam Pao Dam, and Laem Non Wiset (Kalasin).

\section{Research Methodology}

This study was conducted using a qualitative approach in the provincial Roi Kan Sarn Sin cluster, located in northeastern Thailand. The cluster consists of study sites in four provinces, encompassing Roi Et Province, Khon Kaen Province, Mahasarakham Province, and Kalasin Province, as shown on the map in Figure 1.

The provincial cluster is full of religious tourism resources such as Nong Wang Royal Temple in Khon Kaen province, or Klang Ming Muang Royal Temple in Roi Et province. In addition, this area located in the center of Northeastern region which is convenient for travelling, and it can be linked to other natural attractions in the Northeastern region.

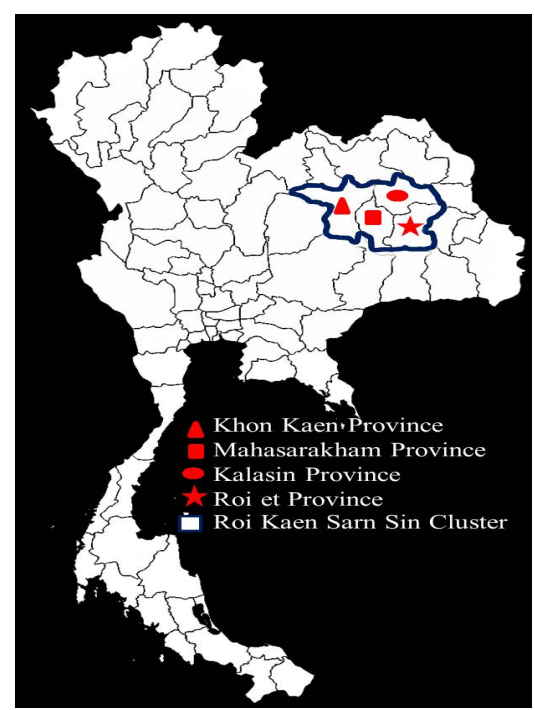

Figure1. Roi Kaen Sarn Sin cluster

\subsection{Key informants}

The key informants are 15 officers from government and private sectors who get involved in tourism. They include eight representatives from the tourism sector who have worked in the area for more than five years and know very much about tourism in this area. There are seven representatives from the tourism business association who operated tourism activity in this area.

\subsection{Tools}

The semi-structured interview (SSI) was used to collect data, along with the recorder, and observation guidelines (checklist) (Sujin \& Sukasini, 1987). The interview guideline was created by focusing on the elements of religious tourism resources in the RKSS cluster area.

\subsection{Data analysis}

Content analysis was used to identify the data elements, and a matrix table was used to analyze the qualitative data.

\section{Results and Discussions}

\subsection{Potential of Religious Tourism Elements in the RKSS Cluster}

Interviews with key informants were conducted about the potential of the religious tourism element in the RKSS cluster, and it was found that religious tourism consists of the following seven elements: 
1) Attractions: Religious tourist attractions in the Roi Kaen Sarn Sin cluster are mostly related to the monasteries and archaeological sites, especially the temples, where most people would like to visit in order to seek positive feelings (peace, Dharma). This result conforms to Alecu (2011), who has stated that religion is a source of spiritual insight for the people. Most of the religious attractions are in the countryside.

2) Accessibility: The transportation system which links the provinces within this cluster is very convenient, especially for those traveling by private vehicle. Traveling by air and rail is also popular; by the way, the convenience of public transportation is available within urban areas only. Public transportation is not quite supportive of tourism in the case of the attractions located in the countryside, but it would be convenient to travel by car. This issue is very important because public transportation would increase the opportunities for travelers who want to visit the attractions out of town (Matei, 2005).

3) Accommodations: This is the strength issue of tourism in the Roi Kaen San Sin cluster because there are many types of accommodations to serve the tourists. Accommodation is also a factor that is directly related to religious tourists, so this issue has to be the primary one that all tourism sectors have to consider (Ebrahimzadeh et al., 2011)

4) Safety: Safety for tourists who travel to Roi Kaen Sarn Sin attractions is excellent; the tourism-crime statistics are very low compared to other areas. Safety is a critical factor for supporting decision making by travelers, and it must be considered top priority (Darvill, 1994).

5) Activities: The activities supporting religious tourism in a Buddhist country are many, especially on important religious days, which are supported a lot by the public, private, and citizen sectors. Few other activities support tourism year-round. In addition, more activities support religious tourism in areas such as conferences and local festivals. This results in a positive impact on religious tourism, and it also affects cultural conservation within the area (Galvani, 2005).

6) Social issues: The community has realized the better economic status it gets from tourism. This caused locals to begin developing their areas to support tourism activities more, and their development also is a good sign for starting eco-tourism in other ways (D'mello, 2008; Ratanakomut, 2006; OECD, 2009).

\subsection{Weaknesses and Opportunities of the RKSS Cluster}

Interviews with stakeholders regarding tourism in the provincial cluster discussed the highlights of religious tourism, opportunities for tourism, and present weaknesses. These issues are shown in Table 1.

Table 1. SWOT analysis of resource elements for religious tourism in the RKSS provincial cluster

\begin{tabular}{|c|c|}
\hline Strength & Weakness \\
\hline $\begin{array}{l}\text { 1. The cluster is in a central region that can } \\
\text { connect to other areas. }\end{array}$ & $\begin{array}{l}\text { 1. Low management within the attractions, especially the } \\
\text { shops in tourist areas. }\end{array}$ \\
\hline $\begin{array}{l}\text { 2. The transportation is comfortable, such as the } \\
\text { airport in Khon Kean and Roi Et and super }\end{array}$ & $\begin{array}{l}\text { 2. No integration among agencies related to the tourist } \\
\text { attractions. }\end{array}$ \\
\hline h1ghways conne & 3. Public transportation provisions still limited to \\
\hline $\begin{array}{l}\text { 3. It has a lot of accommodations such as rest } \\
\text { areas or hotels. }\end{array}$ & $\begin{array}{l}\text { 4. Tourist focus only on attractions' sacredness, but } \\
\text { conservation and other awareness lacking. }\end{array}$ \\
\hline & 5. Low restroom quality, which is important to visitors. \\
\hline & ther kinds of \\
\hline essibility to tourism places. & le to support attraction \\
\hline ls and & access. \\
\hline onth. & 8. Funding not supported by the government, only donations \\
\hline 7. There are too many Buddhis & from \\
\hline 8. Almost all Thai people are Buddhist. & 9. Only one type of activity in these attractions. \\
\hline 9. Mon & 10. I \\
\hline & org \\
\hline Thai & lanage the tourists. \\
\hline $\begin{array}{l}\text { 11. It has a network of tourism companies and } \\
\text { governments. }\end{array}$ & $\begin{array}{l}\text { to visit on their own, do not need business } \\
\text { em. }\end{array}$ \\
\hline $\begin{array}{l}\text { 12. There are many organizations to set up } \\
\text { conferences and seminars in the RKSS cluster. }\end{array}$ & 13. No low-cost airlines operating in the provinces. \\
\hline
\end{tabular}




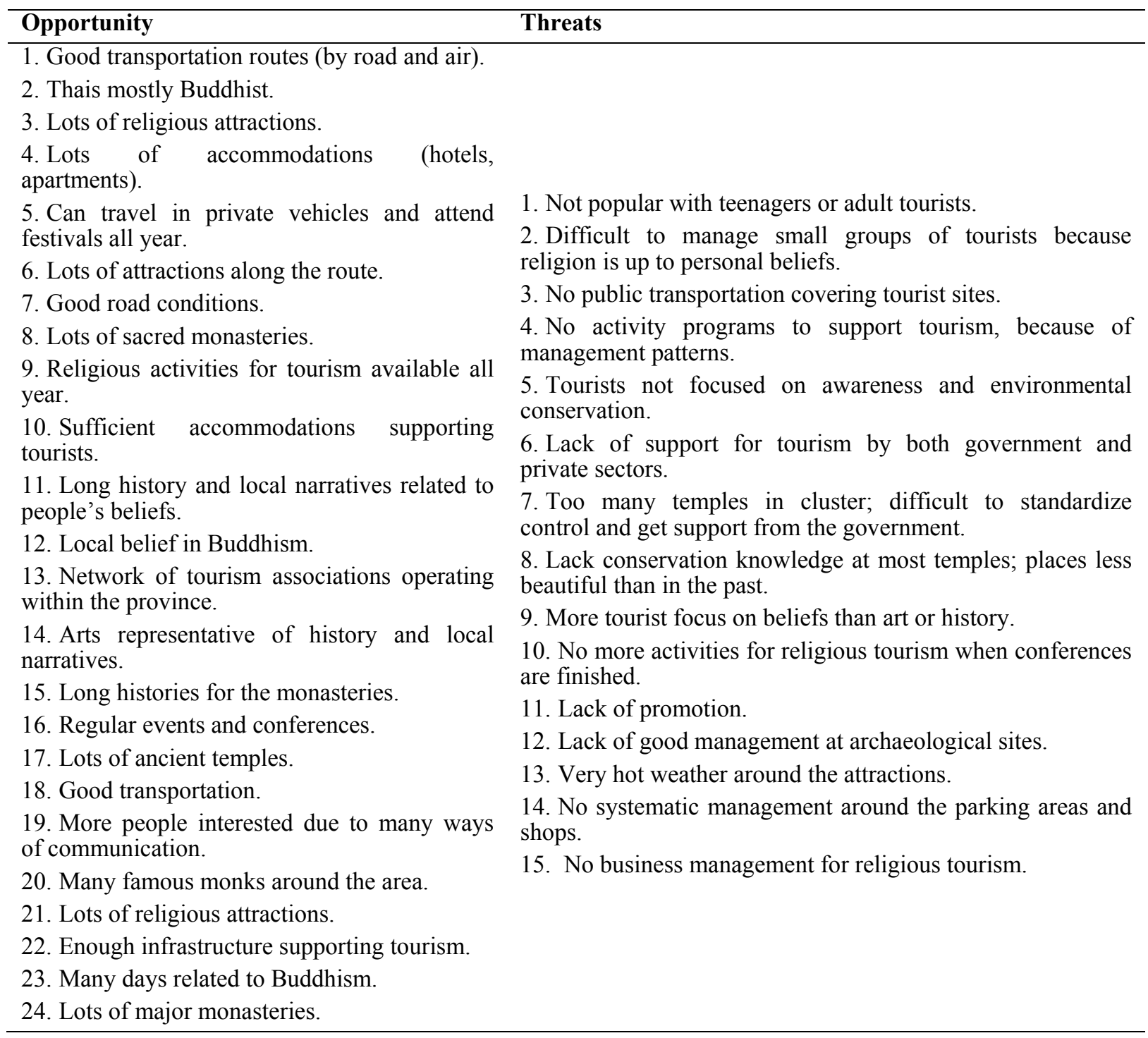

The SWOT analysis of religious tourism found 12 strengths, 14 weaknesses, 24 opportunities, and 15 threats, so attractions can be classified by several issues, including infrastructure and transportation, tourist attractions, religious activities, networks, and beliefs.

Infrastructure and transportation includes facilities for tourists such as electricity, water supply, Internet, water, and accommodations. Michael et al. (2009) reported the importance of infrastructure that is pleasurable to tourists; it is a factor in convincing tourists to visit again. These could help tourists manage or set their tourism schedules more easily (Mika, 2010).

1) Tourist attractions: These are the monasteries and archaeological sites; this group would relate to people's beliefs and any sacred things which appear locally. Religion is an ideal that is imparted to people, and it also acts as an anchor of people's souls (Becker, 1973; Solomon et al., 2004). It may be said that monasteries are places without fear (Pearce et al., 1996).

2) Religious activities and beliefs: The faith of the people is an important thing which supports religious activity, especially during the important religious days such as festivals. These activities have been transferred from generation to generation and serve as local narratives, and they train the mind (MONASTIC) to affect practitioners' feelings (Wong et al., 2013).

3) Network operators: Each province will have tourism operators run businesses through networks linked across the provincial cluster. It is difficult to classify this kind of tourism because most of the religious tourists are locals who are already staying in the community or religious groups that come to visit the religious places for other purposes. This makes it difficult to manage the system. 


\subsection{Weaknesses of Religious Tourism in the Provincial RKSS Cluster Have to Be Developed}

1) Public transportation: Monasteries or sacred places are located throughout the northeastern region, so public transportation is necessary in order to handle the numbers of tourists who are going to visit. Currently, private car is a popular transportation method for carrying tourists to visit the attractions.

2) Internal management within the monasteries: Management also includes landscaping and management in shops and restaurants. Cleanliness is also important, especially in restrooms. The cleanliness of restrooms in the religious places poses such a great disadvantage because most of the lavatories use septic tanks, so it is difficult to keep them clean all of the time.

\subsection{Opportunities to Enable the Provincial RKSS Cluster to Develop Religious Tourism}

1) Transportation: Location of this provincial cluster is in the center of the northeastern region, where it is easy to link with neighboring regions and countries. There is a main transportation route which connects the provinces, and there are two airports in this provincial cluster.

2) Monasteries: There are lots of monasteries located around the area. This region has even been selected as the pilgrimage route (making merit) supported by Tourism Authority of Thailand (TAT.). The majority of the country is Buddhist. The study also found that the people within the local area are a main group for religious tourism management.

\section{Conclusion}

The northeastern region of Thailand is an archaeological site reflecting the area's human civilization, especially in term of religion. The RKSS provincial cluster is located in the center of the northeastern region, and it is a land filled with unique local culture. This study aims to investigate the religious tourism elements to find a suitable management approach to religious tourism. The study was done using a qualitative approach. Semi-structure interview guidelines were used with key informants, including officers from the government and private sectors, concerning tourism in the area. The results found that religious tourism took place within this area a long time ago. Tourism elements of religious tourism in the RKSS cluster include 1) attractions, 2) accessibility, 3) accommodations, 4) safety, 5) activities supporting tourism, and 6) social issues. Opportunities and weaknesses in the RKSS provincial cluster can be classified into several categories, including infrastructure and transportation, tourism attractions, religious activities, networks, and local beliefs. This study found 12 strengths, 14 weaknesses, 24 opportunities, and 15 threats. The resulting development strategies for increasing potential for religious tourism are transportation coverage to public transportation. The government should improve roads (good condition) for connecting with provinces and enable sightseeing in the rural areas. Second, monasteries should keep their restrooms clean and good management among the people in the community, monks, and the local government should occur, including landscape management.

\section{References}

Alecu, I. C. (2011). Epistemological aspects of religious tourism in rural areas. International Journal of Business, Management and Social Sciences, 2(3), 59-65.

Angeles, R. G., \& Javier, D. E. C. (2008). Religious events as special interest tourism. A Spanish experience. PASOS. Revista de Turismo y Patrimonio Cultural, 6(3), 419-433.

Becker, E. (1973). The denial of death. New York: Free Press.

Boupan, P. (2002). Report: Economics of Isan community in $5^{\text {th }}$ decade after second warrior: A case study in Ban Tha. Bangkok: Thailand Research Fund.

D'mello, C. (2008). Transforming re-forming tourism: Perspectives on justice and humanity in tourism. Chiangmai: Thailand.

Darvill, T. (1994). Planning, tourism, and cultural landscapes. Tourism Recreation Research, 19(2), 59-64.

Ebrahimzadeh, I., Kazamizd, S., \& Eskandari, S. M. (2011). Strategic planning for tourism development, emphasizing on religious tourism (case study: Qom City). Human Geography Research Quarterly, 76(2), 19-21.

Galvani, A. (2005). The sustainable tourism for the Europe of the third millennium. Retrieved from http://amsacta.cib.unibo.it/2569/1/GalvaniTourism.pdf

Greek National Tourism Organization. (2011). Religious Tourism. Ministry of Culture and Tourism. Greek. Retrieved from http://www.vtt.cz/upload/images/pdf_nova/religious.pdf 
Istvan, E., Bayram, B., Fatih, K., \& Ozan. A. K. (2012). Unlocking the potential of religious tourism in Turkey. GeoJournal of Tourism and Geosites, 1(9), 63-80.

Katri, N. (2012). Religious Tourism: A Finnish Perspective. Retrieved from https://publications.theseus.fi/bitstream/handle/10024/51755/Nieminen_Katri.pdf?sequence=1

Manu, W. (1977). Settlement in rural Thailand. Bangkok: Silapakorn University, Thailand.

Matei, D. (2005). Turism rural. Teoriesiaplicație. Iasi: Terra Nostra Publishing House.

Mekonnen, G. E. (2010). Information technology: Its uses in the tourism industry. Catering and Tourism Training Institute. $\quad$ Retrieved from http://195.130.87.21:8080/dspace/bitstream/123456789/730/1/IT\%20in\%20Tourism,\%20Mekonnen.pdf

Michael, A. P. T., Simon, B., Nicholas, H., \& Ali, H. (2009). Local infrastructure in Australian tourist destinations: Modelling tourist demand and estimating costs of provision and operation. Australia: CRC for Sustainable Tourism Pty Ltd.

Mika, L. (2010). Public infrastructure investments and their role in tourism development in the Finnish lake region. Lake Tourism Project. Savonlinna Institute for Regional Development and Research, University of Joensuu. $\quad$ Retrieved from http://www.uef.fi/documents/1145891/1362837/mika_iltcpaper.pdf/59cca4f7-ffff-48e3-96bb-65bff11d9a51

Office of Strategy Management. (2011). Strategic plan of the lower-northeastern provincial cluster Roi Et-Khon Kaen-Mahasarakham-Kalasin “Roi Kaen Sarn Si.” Khon Kaen: Office of Strategy Management (OSM), Roi Kaen Sarn Sin, Khon Kaen Office.

Organisation for Economic Co-operation and Development. (2009). Chapter 7: The Vorarlberg Province, Austria: The Impact of Culture on Tourism, 97-113. OECD, Paris. Retrieved from http://www.oecd.org/newsroom/43125523.pdf

Pearce, P. L., Moscardo, G., \& Ross, G. F. (1996). Tourism community relationships. Pergamon, Oxford, UK.

Peter, P. (2011). Tourism: Investing in energy and resource efficiency. United Nations Environment Programme. Retrieved from http://www.unep.org/resourceefficiency/Portals/24147/scp/business/tourism/greeneconomy_tourism.pdf

Ratanakomut, S. (2006, May). Community awareness and cultural tourism sustainability. Paper presented at the APEC Study Center Consortium Conference, Ho Chi Minh City, Vietnam.

Simaraks, S., \& Supatera, S. (1987). Rapid rural appraisal manual. Khon Kaen, Thailand: Farming Systems Project, KhonKaen University.

Smith, S. L. J. (1994). The tourism product. Annals of Tourism Research, 21(3), $582-595$. http://dx.doi.org/10.1016/0160-7383(94)90121-X

Solomon, S., Greenberg, J., Schimel, J., Arndt, J., \& Pyszczynski, T. (2004). Human awareness of death and the evolution of culture. In M. Schaller \& C. Crandall (Eds.), The psychological foundations of culture (pp. 15-40). New York: Erlbaum.

Suvit, T., \& Dararat, M. (1998). History of Isan after second warrior until present. Department of History and Archeology. Khon Kaen: Faculty of Humanities and Social Science, Khon Kaen University.

Tawat, P. (1989). Isan: Past, present, and future, conferences in local culture: Isan case studies. Department of Cultural Promotion and Ubonratchatanee Cultural Center Teacher College on 30 June-2 $2^{\text {nd }}$ July 1989. Bangkok: Amarin Printing Group.

Vidic, N. (2007). Religious tourism as post-modern tourism in the territory of Fruskagora. Retrieved from http://analegeo.ro/wp-content/uploads/2010/07/Articolul-18-Nada-Vidic.pdf

Viorica, A. M., \& Sorin, C. (2010). Forecasting in tourism-an important component of the planning process. Romanian Economic and Business Review, 5(1), 182-187.

Vorzsak, M., \& Gut, C. M. (2009). A strategic prognosis of religious tourism in Romania: Proceedings of the $2^{\text {nd }}$ International Conference on Cultural Heritage and Tourism, 29-34. Rhodos: WSEAS Press. Retrieved from http://www.wseas.us/e-library/conferences/2009/rodos/CUHT/CUHT03.pdf

Wiwat, S. (1995). Hut: A case study in Ubourachathanee, Yasothon, Kalasin, and Sakolnakorn provinces. Khon Kaen Thailand: Faculty of Architecture, Khon Kaen University. 
Wong, C. U. I., McIntosh, A., \& Ryan, C. (2013). Buddhism and tourism: Perceptions of the monastic community at Pu-Tuo-Shan, China. Annals of Tourism Research, 40(1), 213-234. http://dx.doi.org/10.1016/j.annals.2012.09.004

World Tourism Organization. (2011). Religious Tourism in Asia and the Pacific. Madrid, Spain: World Tourism Organization.

\section{Copyrights}

Copyright for this article is retained by the author(s), with first publication rights granted to the journal.

This is an open-access article distributed under the terms and conditions of the Creative Commons Attribution license (http://creativecommons.org/licenses/by/3.0/). 